\title{
$\underline{\text { Moscow, Havana and Asymmetry in International Relations }}$
}

\begin{abstract}
Asymmetric relationships have been fundamental to the study of International Relations, becoming even more important with the end of the Cold War which left the United States as the sole global superpower. However, what impact does the distance between the two countries have on the magnitude of an asymmetric relationship and the exposure of the countries to one another? This article examines these phenomena by analysing the relationship between Havana and Moscow from the time of the Russian Revolution in November 1917 to the present. Specifically it will examine three distinct periods; from November 1917 until February 1960, from February 1960 until the implosion of the Soviet Union in late 1991 and from 1992 to the present. This article will posit that the distance between two countries reduces neither the intensity of an asymmetric relationship nor the exposure of the two countries to one another.
\end{abstract}

The various interactions of states are fundamental to the study of International Relations (IR), but due to amongst other things the differences in geographical size, military strength and natural resources which exist between states, IR is dominated by the interaction of actors of unequal size. In short, asymmetric relationships are key to understanding IR. This gives rise to a number of related issues including that of power, but the importance of asymmetry within IR has increased with the end of the bipolarity of the Cold War which left the United States as the one remaining superpower. The result is that all of the United States' relationships are asymmetrical in nature.

On the differences between states Thucydides has famously written 'the strong do what they can and the weak suffer what they must' (Thucydides 1951, 331). More recently Brenner has written 'Great powers tend to dominate small powers within the realm of what they consider to be their sphere of influence' (Brenner 2006, 280), or as Womack has stated in his body of work on asymmetry 'size matters' (Womack 2012, 123). However, is the magnitude of an asymmetric relationship affected by the distance between the two countries? 
Writing abstractly about this Womack has stated that 'the intensity of asymmetric relationships usually varies inversely with distance. If the distance between A and B is increased, then the overall salience of the relationship is reduced' (Womack 2003, 96; Womack 2006, 77). In sum, the intensity of an asymmetric relationship is proportional to the exposure of the two countries to one another. This article will examine the concepts of asymmetric relations and distance, and the supplementary question of whether asymmetric effects are indifferent to distance, which in the twenty-first century have increasing importance for IR in general.

An analysis of the relationship between Cuba and Russia, and before it the Soviet Union will achieve this. Not only are there over 5,900 miles or 9,500 kilometres between Moscow and Havana, but the relationship also appears to be a perfect example of an asymmetric relationship. In 2014 Russia had 20 times the military personnel of Cuba and the Russian Federation's global trade turnover was 42 times higher than that of the Caribbean island (globalsecurity.org; International Trade Statistics Yearbook, 310: Annuario Estadistico 2013: 8.4-8.6).

This article will examine the relationship between Moscow and Havana from the time of the Russian Revolution in November 1917 until the present using Womack's work on asymmetric power. The bilateral relationship can be divided into three distinct periods. The first is from November 1917 until February 1960 when the first economic agreement between the Soviet Union and Cuba after the Cuban Revolution was signed (Navarro and Duarte 2006: 59). This marked the beginning of a close political and economic relationship that would persist for the next 30 years. Sporadic contact between the two countries had taken place before November 1917 (Mamedov and Dalmau, 2004, 13), but the appearance of the Bolshevik government in Moscow commenced Russian 'systematic' interest in Cuba. The 
second period is from February 1960 until the implosion of the Soviet Union in late 1991 and the third from 1992 to the present.

This will twice allow a relationship between a socialist and capitalist country and also a relationship between two socialist countries to be analysed due to various political changes in both countries over the last 100 years. Additionally, due to the nature of Cuban-U.S. relations, and the bipolarity of the Cold War period, this article will also provide an analysis of a weaker state vying for its strategic interests from one of the global hegemonic powers in the 1960 to 1991 era while simultaneously the two global hegomons contended with each other. Moreover, in the post 1992 period the situation became further complicated as not only does Cuba have an asymmetric relationship with both Russia and the United States, but Moscow also has an asymmetric relationship with Washington. This will permit the article to examine the importance of geographic distance in an asymmetric relationship over both an extended period of time and under various different political situations.

In order to maintain a neutral position this article will utilize a range of primary and secondary sources including government documents, speeches, official statistics from both countries and third-party organisations and media reports. It will commence with an examination of asymmetric power in IR before analysing the three distinct periods of the relationship in chronological order. Finally a discussion on the bilateral relationship using Womack's body of work on asymmetric power will be provided.

Asymmetry in International Relations

A body of literature exists regarding asymmetry in IR with Womack in his work on asymmetry stating 'Clearly asymmetry must be accepted as a permanent feature of some 
relationships, and as a common feature of the general matrix of international relations' (Womack 2003, 94-95). Moreover, Womack has argued that culture in Huntington's Clash of Civilisations is not the key issue but rather asymmetric relationships, further increasing the significance of asymmetry within IR. He has written 'It is the asymmetry of the relationship between the United States and the rest of the global village rather than the distance between civilisations that is the crux of the problem' (Womack 2010, 278).

Traditionally the perception exists that it is advantageous to be the larger power in a relationship and writing about asymmetric warfare Schmitt has written 'it is in the very nature of warfare to seek strategies, tactics, and weapons that either leverage one's own strengths (positive asymmetry) or exploit the enemy's weaknesses (negative asymmetry)' (Schmitt $2007,10)$. Brenner has also written about the behaviour of the larger country in an asymmetric relationship and that its motives vary and can be underpinned by moral reasons or the desire to spread democracy or modernisation to a smaller neighbour. This still entails the larger power imposing its will on the smaller country. Conversely Brenner has written 'Small powers tend to calculate their international behaviour in terms of the great power in their neighbourhood' (Brenner 2007, 281). This was written regarding Cuban-U.S. relations, but is applicable on a global scale and certainly for the former Soviet republics with Russia.

The result is that the relationship appears more important for the smaller country and this can lead to inattention by the larger power (Womack 2003, 101). Regarding this Womack has written

In each bilateral relationship asymmetry structures the perspective, attention, and interactive behaviour of each side. The smaller partner is proportionally more exposed to both the opportunities and the risks of the relationship; therefore it will be more 
attentive. The larger side is less exposed and is distracted by other more important relationships. Thus the smaller side will be quick to adjust policies and more anxious about negative possibilities, while the larger is likely to be inattentive except in crisis situations, and even then its primary concern is reaching closure and moving on to more important matters. (Womack 2010, 6).

Furthermore, Womack believes that the cohesive nature of the structure of foreign policy making in communist societies adds to the possibility of misperception (Womack 2003, 107). This appears to have resonance for Moscow's relationship with Havana.

However, the larger power in a relationship is not always able to impose its will on the smaller country with Womack having written 'Moreover, a disparity of power does not mean that the more powerful simply dominates the less powerful. The name 'Vietnam' should be a rueful reminder of that to an American, French or Chinese audience' (Womack 2003, 95). This is also applicable for both Havana's relationship with Moscow and Cuba in general due to the foreign policy pursued by its revolutionary government since 1959 .

Slobodchikoff has also addressed the issue of the larger country dominating the smaller one in his work on Russia's relationships with the former Soviet states. In the early 1990s the newly independent states may have been wary of Moscow's economic, political and military power, but through a complex set of discussions on both bilateral and multilateral agreements a stable regional order has been created. Russia may be the regional hegemon, but concessions from both Moscow and the former Soviet states were necessary for the success of these discussions (Slobodchikoff 2014). Moscow being unable to impose its will on smaller nations is not restricted to the post-Soviet era as Slobodchikoff also details the skilful negotiating technique of Finland during the discussions which eventually led to the 
1948 Friendship and Cooperation Treaty between the two countries (Slobodchikoff 2014, $34)$.

An asymmetric relationship does not have to be antagonistic with Womack believing that the coexistence of small and large states demonstrates the stability of asymmetry (Womack 2006, 89-91). Womack has detailed nine different types of asymmetric relationships that can exist and that over time a bilateral relationship can move from one form to another. The optimal situation may be a normalised relationship with Womack writing, 'Normalised asymmetry does not function by pre-emptying asymmetric differences, but by managing their consequences' (Womack 2006, 247). On the opposite end of the historical spectrum is an amorphous relationship that exists 'between regions that are not organised as political communities.' The example provided is urban America (Womack 2006, 239-241). Womack describes an internal asymmetric relationship as one which exists between a central government and its regions with the examples offered being Texas and the United States and Paris and Lyon (Womack 2006, 240-242). A subjugated relationship is 'between a dominant unit and a distinctive subordinate community' which was most evident in colonial relationships (Womack 2006, 240, 242). Moreover, when collision is the major point of contact between two countries Womack believes that this displays the central tenets of disjunctive asymmetry. The example offered is the United States and Native Americans (Womack 2006, 240, 243).

The types of asymmetric relationships that appear to have resonance for Moscow's relationship with Havana are role, distracted, dependent, hostile and even normalised. The examples that Womack offers for these types of asymmetric power are Thailand and Cambodia, feudal relationships, Japan and the U.S. and Canada and the U.S., respectively (Womack 2006, 240). Detailing the ideas of role asymmetry, Womack has stated that it 
'exists between autonomous units arranged in an explicit structure of superiority and inferiority' (Womack 2006, 243). Writing about distracted asymmetry, Womack has written that this 'occurs when both sides have to confront more important relationships' (Womack 2006, 245). Dependent asymmetry occurs when 'the weaker side was under the duress of not having a feasible alternative to compliance with the stronger side. This situation pre-empted real negotiation and put the apparent discretion in managing the relationship in the hands of the stronger partner' (Womack 2006, 245).

Hostile asymmetry occurs when one or both countries are perceived as denying minimal levels of autonomy or deference to the other' (Womack 2006, 246). In his work on China and Vietnam, Womack states that this occurred in the bilateral relationship between these two countries from 1973 to 1991 . However, before the first tentative steps to a normalisation process began in December 2014, Havana's relationship with Washington was often perceived as the exemplar of a hostile asymmetric relationship (Womack 2010, 24). Furthermore, Womack also uses this relationship to highlight when a hyperpower can simply ignore global opinion on a certain issue as the U.S. does with its economic embargo against Cuba (Womack 2014, 143). Very different from a hostile asymmetric relationship is normalized asymmetry on which Womack has written 'does not imply a completely harmonious relationship but rather one based on the general expectation of mutual benefit' (Womack 2006, 246). Role distracted, dependent, hostile and normalised asymmetry will be returned to throughout this article in the analysis of both how the magnitude of the asymmetric relationship between Moscow and Havana from November 1917 to the present has been affected by the geographical distance between two countries, and also if asymmetric elements are indifferent to distance. 
As detailed, Cuban-U.S. relations were often cited as the exemplar of both a hostile asymmetric relationship and also when a hyperpower can simply ignore global opinion regarding a certain issue, the economic embargo against the island (Womack 2014, 143). However, the United States' political and economic domination of Cuba in the years from its independence until 1959 was the catalyst for Soviet interest in Cuba. The Platt Amendment of 1901was symbolic of the political 'influence' Washington wielded in this period while the economic control was evidenced by the reciprocity agreements of 1903 and 1934 which very much favoured the United States (Thomas 1971, 469; LaFeber 1989, 72; Pérez 2003, 160).

The outcome was increased labour radicalism and strikes which gave the island the appearance as a 'hot bed' of labour activity. The result was that an unforeseen consequence of the U.S. domination of Cuba was that it appeared that the potential for revolutionary success was greater in Cuba than elsewhere in the region. This only increased still further in 1942 when Juan Marinello and Carlos Rafael Rodríguez became the first Communist Party members in Latin America to hold governmental positions; further demonstrating the 'successes' of the Cuban Socialist Party (PSP). ${ }^{1}$

The Third International, or Comintern, showed interest in Cuba in the 1920s evidenced by the island gaining candidate membership of the Central Bureau of the Comintern at the organisation's Sixth Congress in 1928 and by a number of letters sent from this organisation in early 1928 detailing tactics which the Cuban Communist Party (PCC) should follow. ${ }^{2}$ The PCC were heavily involved in the August 1933 strike which Carr has

\footnotetext{
${ }^{1}$ Sweig 2002, 126. In addition, the Cuban Communist Party (PCC) changed its name to the Cuban Socialist Party (PSP) in the summer of 1944.

2 Adibekov et al 1997, 140-146. Letter from Secretariat of the Communist International to PCC, 5 January 1928, 1). Russian State Archive for Social and Political History (RGASPI) RGASPI Folio 495,Opus105, No10, 1-7.
} 
described as 'the most substantial revolutionary opportunity seen in Latin America before the 1950s' (Carr 1998, 247-248).

The outcome was that any revolutionary success in Cuba could have negative consequences for the United States due to the level of U.S. investment in the island. The interlinked nature of the two economies and resulting Cuban economic dependence on the U.S. could be utilised by Moscow to counter anti-Soviet U.S. policy elsewhere in the world. This included attempts to destroy the Bolshevik Revolution in its infancy, the nonrecognition of the Soviet Union until 1933 and the eventual onset of the Cold War in the mid to late 1940s.

This and the island appearing to be a 'hot bed' of labour radicalism are also key for the Institute of Cuban-Soviet Cultural Exchange in Havana being opened in the summer of 1945, publishing the monthly journal Cuba y la URSS until the spring of $1952 .{ }^{3}$ Significantly the Soviet Society for Cultural Relations with Foreign Countries (VOKS) was heavily involved in both the institute and the material which was published in this journal (Bain 2013, 96-108). Writing about VOKS in general, Stern has written, 'From its creation, VOKS began to manifest an underlying political agenda - that of promoting the Soviet system in the West by means of cultural cover' (Stern 1999, 109). Soviet 'soft power,' was fundamental for these activities, which aimed to increase Soviet political influence on the island, thus simultaneously reducing U.S. political influence.

Soviet-U.S. tension appeared to be the principle factor in the Soviet Union's relationship with Cuba as Moscow could utilise the relationship to counter anti-Soviet U.S. policies elsewhere. Moreover, in this period Havana's relationship with Washington was the

\footnotetext{
${ }^{3}$ It was discontinued when diplomatic relations between Moscow and Havana that had existed between October 1942 and April 1952 came to end in the aftermath of Fulgencio Batista's return to power (Pravda 5 April 1952, $3)$.
} 
island's most important relationship. Moscow's relationship with Havana, and Havana's relationship with Moscow was simply not the most important relationship for either country. In sum, an example of distracted asymmetry, on which Womack has written 'occurs when both sides have to confront more important relationships (Womack 2006, 245). Additionally, the geographical distance between the Soviet Union and Cuba did not reduce the intensity of the relationship in this period as Moscow's interest in the island existed despite it.

The idea of Moscow-Havana relations in the period from November 1917 to February 1960 displaying distracted asymmetry begins to be questioned by the interest Moscow showed in buying Cuban sugar with tentative interest being as early as 1921 (Mamedov, and Dalmau 2004, 29). The first Soviet purchase of Cuban sugar was in the 1950s, significantly after diplomatic relations had been severed. Crucially the Soviet Union required sugar as its agricultural output was at a low level eventually heralding the implementation of the Virgin Lands Project (Hosking 1992, 356-358). Cuba was one of the world's largest producers of sugar at this time and it was logical that Moscow would turn to Cuba (Vneshniaia torgovlia SSSR 1967, 68-69).

The Kremlin buying Cuban sugar when Soviet agricultural output was low could even suggest that a form of dependency had arisen. Furthermore, with the Soviet Union acquiring a much needed commodity and Cuba receiving financial remuneration this situation was mutually beneficial. This appears to be in accordance with Womack's aforementioned quote regarding normalised asymmetry. This will be more fully examined later, but in this period the relationship displayed elements of different types of asymmetry. Importantly this was unaffected by the distance between the two countries with the effects of asymmetry appearing indifferent to distance. Moreover, a degree of exposure between Moscow and Havana had taken place with their respective relationships with Washington being paramount for this. 
In January 1959 Moscow may have been unsure of what type of revolution had taken place in Cuba, but a number of reasons made the events in Cuba of great interest for the Kremlin. ${ }^{4}$ The Cold War was at its height and after Joseph Stalin's death in March 1953, Soviet foreign policy had become much more expansive in nature (Light 1988, 99-124). Moreover, the anti-American nature of the Cuban revolution and the island's geographical location were key (Fursenko and Naftali 1997, 27). A burgeoning relationship with the new Cuban regime illustrated both the Soviet belief that the Cold War was turning in its favour, and also highlighted to Washington that Moscow had both gobal aspirations and could also challenge U.S. hegemony not just in Latin America, but even Cuba. Moreover, the support and guidance which Moscow could provide for the new Cuban regime would also answer Chinese questions of Soviet revisionism (Bain 2008, 23).

The role of the United States and Cold War geopolitics also underpinned the interest which the Cuban Revolution took in Moscow. The Cuban revolutionary government wished to fundamentally alter its relationship with Washington, primarily due to both the nature of Cuban-U.S. relations detailed above and the prominence of nationalism within the revolution. Fidel Castro would later comment, 'We would not in any event have ended up as close friends. The U.S. had dominated us for too long. The Cuban Revolution was determined to end that domination' (Smith 1987, 144). This situation was further complicated by U.S. aggression towards Cuba . In the Cold War setting if Havana did not have good relations with Washington, it required them with Moscow. Furthermore, the Cuban government was

\footnotetext{
${ }^{4}$ Aleksandr Alekseev, the first Soviet citizen to be granted a visa to travel to Cuba after the victory of the revolution, made this very point (Fursenko and Naftali, 1997, 27). Andrew and Mitrokhin have detailed the involvement of the KGB in the first tentative contact made between the Soviet Union and the new Cuban government which commenced soon after January 1959 with this highlighting the interest that Moscow took in the fledgling revolution in Cuba (Andrew and Mitrokhin 2005, 35-39).
} 
also drawn to both the Soviet economic and political models as these would be decisive for the construction of the new society in Cuba which the revolutionary government desired (Bain 2007, 20-21).

The personal affinity that blossomed between Nikhita Khrushchev and Castro was also important as the Soviet leadership were simply 'seduced' by the appearance of the young revolutionaries in the Caribbean. By the early 1960s the Soviet leadership consisted of middle-aged career politicians with the Cuban Revolution not only revitalising the Soviet ruling elite, but also the Soviet revolution itself. Regarding this, Anastas Mikoyan, a member of the Presidium of the Communist Party of the Soviet Union (CPSU), would comment, 'You Americans must realize what Cuba means to us old Bolsheviks. We have been waiting all our lives for a country to go communist without the Red Army. It has happened in Cuba, and it makes us feel like boys again' (Farber 2006, 147).

As with the period from November 1917 to early 1960, Soviet-U.S. relations were key for Moscow's relationship with Havana as the Kremlin could utilize its relationship with Cuba to increase its power vis-a-vis Washington. However, by the early 1960s this had become even more important due to the intensification of superpower rivalry. The sceptre of the United States was also evident in Castro's announcement of December 1961 that he, and thus the Cuban Revolution, were Marxist-Leninist. It is perceived that this announcement was made in an attempt to gain security guarantees from Moscow, which were essential due to the aggression which Cuba faced from the United States (Shearman 1987, 10-11).

The two countries became increasingly 'tied' together by the outcome of the Cuban Missile Crisis, despite Cuba being deeply unhappy at its omission from the talks which brought a resolution to the crisis (Fursenko \& Naftali 1997, 290-315). After the risks which Moscow had taken in deploying missiles to Cuba, the Soviet leadership simply could not 
allow the Cuban Revolution to fail because if it did, its already damaged global prestige would have been further dented.

This is repeated with the Soviet economic investment in the Cuban economy which would have been wasted if the Cuban Revolution failed. Estimates suggest that the Soviet investment in the period from early 1960 until late 1991 could have been as high as $\$ 100$ billion (Sevodnya 13 Jan 1995, 3). Additionally, the Soviet Union had also 'invested' expertise in the Cuban economy due to the number of Soviet specialists who had worked on the island and that some 8000 Cubans per year studied in the Soviet Union (Lavrentyev 1985).

Moreover, bilateral trade increased exponentially during this period reaching almost 10 billion pesos by the mid-1980s (Anuario Estadístico de Cuba 1990). Soviet exports to Cuba dominated trade with Azicri describing Cuba's relationship with the Soviet Union as 'the lifeline of the economy' (Azicri 2000: 21). Cuba's chief export to the Soviet Union was sugar. In 1980 the level of Cuban sugar sales to the Soviet Union was 2.026 billion pesos rising to 3.6 billion pesos in 1985 , representing $89 \%$ and $82 \%$ of Cuba's exports to the Soviet Union, respectively. This figure remained above $70 \%$ throughout the 1980 s despite the terms of trade turning against Cuba as the decade progressed (CEPAL 1990, 321; Bain 2007, 30-32).

Significantly both countries gained from the economic aspect of the relationship. Trade with the Soviet Union was vital for Cuba due to the importance of trade for the revolution's economic security and the Soviet Union also received much needed sugar. Moreover, if the Cuban Revolution imploded, Moscow would lose the relative gains the relationship provided vis-à-vis the United States. 
In this period, Cuba was able to defy the regional hegomon while also being able to exert leverage in its relationship with the other global superpower and not bend to the rules of asymmetric power created by the larger power in the relationship, the Soviet Union. Castro did this repeatedly, most famously demonstrated in the mid-1970s when Havana took the decision to send troops to Africa first, leading subsequently to Soviet involvement (Rodríguez 1981; Erisman 2000, 43-47; Bain 2007, 23-27).

As in the period from November 1917 until February 1960, Moscow and Havana's respective relationships with Washington were fundamental for Soviet-Cuban relations. The result was that again the relationship displayed distracted asymmetry, which as previously stated 'occurs when both sides have to confront more important relationships' (Womack 2006, 245), but it had intensified due to both the symmetry of superpower Cold War rivalry and also the tension which existed in Cuban-U.S. relations. As detailed, Womack has described this as the exemplar of a hostile relationship (Womack 2010, 24), which could suggest that Soviet-Cuban relations provided the exemplar of a distracted relationship.

However, the situation is more complicated. Using Womack's definition of distracted asymmetry implies that Cuba's relationship with the United States was its most important relationship, but this is questioned due the importance of Soviet-Cuban relations, politically and economically, for the island, . Moreover, after December 1961 it can be argued that Havana's relationship with Moscow was not driven purely by the hostility of the United States towards both countries, but instead by Marxist-Leninism. This questions the type of asymmetric relationship that existed between Moscow and Havana in this period.

Furthermore, the relationship also provided Moscow with an important source of sugar with this postulating that Soviet-Cuban relations also displayed elements of dependent asymmetry. As with the earlier period, forms of Soviet dependency on Cuban sugar were 
evident, but Cuba was economically dependent on the Soviet Union. Again this could suggest normalised asymmetry existing due to the mutually beneficial nature of the relationship for both countries. Moreover, in the 1960 to 1991 era Cuba was described as a superclient/surrogate of the Soviet Union with Havana merely acting on the behest of the Kremlin. ${ }^{5}$ This would suggest the presence of political dependence as it is in accordance with Womack's assertion that dependent asymmetry occurs when 'the weaker side was under the duress of not having a feasible alternative to compliance with the stronger side (Womack 2006, 245).This will be examined more fully later in the article, but it would also posit that role asymmetry could be used to describe the relationship.

The type of asymmetry which existed in this period may be uncertain, but what is beyond question is that the geographical distance between Moscow and Havana did not reduce the intensity of the relationship. Moreover, it was not the almost 6000 miles between Moscow and Havana that was significant, but rather the 90 miles between Cuba and the United States. Soviet-Cuban relations were intensified due to the geostrategic significance of Cuba for the Kremlin. This implies that asymmetric effects are unaffected by distance, but crucially both the exposure of the two countries to one another and the magnitude of relationship had increased when compared to the earlier period, primarily from the rivalry which existed in the symmetry of Soviet-U.S. relations.

\footnotetext{
5 Regarding Cuban military action in Africa in the 1970s the U.S. Senator Daniel Moynihan has even described the Cuban army as the "Ghurkhas of the Russian Empire" (Erisman 2000, 33-36).
} 
After the end of Soviet-Cuban relations it very quickly appeared that little of its former incarnation remained functioning. Fundamental for this was the victory of the liberal westernizers in the battle which had raged regarding Russian foreign policy (Light 1996, 33100). Internally the Yeltsin government wished to move the Russian economy to a market economy as quickly as possible. 'Shock therapy' was applied in an attempt to achieve this (Shevtsov 2007, 1-24). The result was a western-looking foreign policy as Moscow desired improved relations with the West, but particularly the United States, with the Kremlin also hoping that this would result in aid and assistance from Washington in the Russian economic transition.

This negated cordial relations between Moscow and Havana as hostility continued to emanate from Washington towards Cuba. Shultz and Domínguez have both detailed the importance of the Cuban exile community in the U.S. for this (Shultz 2011, 428-434; Domínguez 1997, 60-62). Domínguez has also written 'An ideological explanation rooted in the rediscovery of historical themes in U.S. policy towards its near-neighbors helps to explain the shift from the Cold War to the colder war' (Domínguez 1997, 60). Political inertia within the U.S. political system, their geographical proximity and, in accordance with Brenner's afore cited quote, the asymmetry that existed between the U.S. and Cuba were also important. In the 1990s U.S. policy towards Cuba became extraterritorial in nature, evidenced by the Cuban Liberty and Democratic Act, or Helms-Burton which contained a section that focused on Russia's continued use of the Lourdes listening post on the outskirts of Havana. ${ }^{6}$ Writing about the role of the U.S. in Moscow's Cuba policy Professor Eugenio Larin, Director of

\footnotetext{
${ }^{6}$ This act stated 'the President shall withhold from assistance provided, ..., for an independent state of the former Soviet Union under this Act an amount equal to the sum of assistance and credits, if any, provided on or after such a date by such state in support of intelligence facilities in Cuba, including the intelligence facility at Lourdes, Cuba' US: Cuban Liberty \& Democratic (Libertad) Act of 1996 (Helms-Burton Act).
} 
Latin American Studies at the Institute of Cold War History of the Russian Academy of Sciences has written, 'In order to improve political ties Washington demanded of B.H. Yeltsin that he must cut ties with Cuba. This course of action dominated the 1990s' (Larin 2007, 164). The downturn in Russian-Cuban relations was demonstrated by Russian voting behaviour at various United Nations (UN) forums from 1992 to 1995 when Russia either voted against Cuba or abstained in votes regarding the Caribbean island (Izvestia 25 November 1992, 5). The Cold War may have ended, but with regards its relationship with Havana, Moscow's relationship with Washington continued to impact considerably on it. Moreover, it could be thought that the normal rules of asymmetry returned with the distance between Cuba and Russia helping facilitate a reduction in the intensity of the relationship and exposure of the two countries to each other.

However, even in the early to mid-1990s a semblance of its previous form continued to function. Key for this was a legacy from the exposure of the two countries to one another from the 1960 to 1991 period. which was both economic and cultural (Bain, 2008 83-106; Loss 2013). Economically this included the Cuban need for oil and spare parts for Soviet era machinery and the Russian need for sugar (Bain 2008, 89-90). Very quickly after 1991 it became apparent that Russia required to continue purchasing sugar from Cuba due to cost and the ease of this practice continuing. On 26 October 1992 Yevgeny Bai, the Izvestia Cuban correspondent wrote, 'Cuba sold the sugar that it had produced last year anyway... while we were forced to buy sugar on the world market through middlemen and at higher prices' (Bai 1992, 7). Additionally, this helped alleviate poor Russian agricultural production levels in the 1990s which had plummeted. This also allowed Russian sugar refineries to continue to work on a 12-month cycle as during the Soviet era due to the import of Cuban sugar as the Soviet and Cuban sugar harvests were out of sync with each other. The loss of this practice had only exacerbated Russia's already poor agricultural output (Glasov, Kara-Murza and 
Batchikov 2007: 111). These legacies of exposure from a previous era existed despite the distance between Moscow and Havana. Furthermore, it also resulted in a level of exposure remaining.

From the mid-1990s the bilateral relationship began to improve, the catalyst being a Russian dislike of its treatment by the West, North Atlantic Treaty Organization (NATO) expansion to the east and the treatment that their fellow Serbs in the former Yugoslavia had received from this organisation. Russian nationalism was gravely offended, manifesting itself in an alteration in Moscow's foreign policy (White 2004, 230).

The outcome was that Russia wished to reassert itself in international relations having been marginalised for a number of years with an improved relationship with Cuba perfectly illustrating this to the United States. In short, Moscow wished to 'tickle the Americans' underbelly' (Sosnovsky 1996, 5). This desire has since continued as the perception exists that the Russian press reports that appeared in July 2014 about the reopening of the Lourdes listening post was underpinned by the deterioration in relations with the West over the situation in the Ukraine which developed throughout 2014 (Kramer 2014).

In short, the geostrategic significance of Cuba has increased. This is not to suggest it has returned to the prominence of the Cold War, but it became even more important with increased Russian interest in Latin America in the twenty-first century. Cuban regional prestige has helped facilitate the Russian desire to increase its influence in Latin America, evidenced in July 2014 when Putin visited Havana and said 'Cuba is one of our principle partners in the region' (Putin 2014). After 1992 Russia's relationship with the U.S. has become asymmetric, but it has continued to impact on Moscow's relationship with Havana.

Russian-Cuban relations were also aided by a change in Cuban foreign policy as the island struggled to adapt to the New World Order of the 1990s. On this Kirk has stated, 'The 
greatest single task in terms of foreign policy facing the Cuban government in the early 1990s, however, was how to keep the traditional (self-declared) enemy at bay' (Kirk 2006, 334). Erisman believes this was achieved by a diversification of the island's foreign policy that aimed to create greater economic and political space (Erisman 2006, 3-5). In order to achieve this Feinsilver has written that Cuba desired'the creation of a Third World constituency' (Feinsilver 1993, 13).

The Russian Federation may not be part of the Developing World, but a relationship with Moscow was not contrary to this process. From the mid-1990s onwards as RussianCuban relations improved, Moscow provided backing for Cuba in its various disputes with the United States in a variety of different international forums, not least UN ones. This was evidenced by Russia being one of only two countries to abstain in the UN vote on 26 July 1996 condemning Cuba over the shooting down by the Cuban air force in February 1996 of two planes belonging to the Cuban American organisation 'Brothers to the Rescue'. ${ }^{7}$ This remains the case even after Cuban-U.S. relations began to improve from December 2014 onwards. Russia continues to call for the end of the U.S. economic embargo against Cuba (Pagliery 2015).

Havana has reciprocated this with Cuba providing important support in the same forums for Russia, evident during both the Georgian war in 2008 and over the Ukrainian situation which unfolded throughout $2014 .{ }^{8}$ With regards their respective relationships with Washington, the relationship is mutually beneficial for both Moscow and Havana.

Furthermore, it would suggest that Moscow's relationship with Havana displayed what Womack has detailed as distracted asymmetry, which 'occurs when both sides have to

\footnotetext{
${ }^{7}$ United Nations (1996), 3683ed Meeting of United Nations Security Council, 26July, http://www.undemocracy.com/securitycouncil/meeting_3683,

8 "Backing Ukraine's territorial integrity, UN Assembly declares Crimea referendum invalid" 27 March 2014. www.un.org.
} 
confront more important relationships' (Womack 2006, 245) or even both normalised and mature asymmetry. These will be examined later. Again the distance between Moscow and Havana has not reduced the intensity of the relationship in the post-Cold War situation with elements of asymmetry appearing unaffected by distance. Moreover, as in the 1960 to 1991 era, it was the geographical proximity of Cuba and the United States that intensified the relationship as the island once again became geostrategically important for the Kremlin. Additionally, Moscow and Washington's Cuba policies were again partly derived from their own rivalry.

The upturn in relations was also economic. Neoliberal economic thinking was pivotal, resulting from the Cuban economic reforms of the 1990s which aided the revolution survive the loss of its socialist trading partners. These reforms opened the Cuban economy to the world market (Pérez- López, 1997; Mesa-Lago, 1993; Mesa-Lago \& Pérez-López, 2005). The upshot was that Russia lost its pre-eminent position in the Cuban economy, evidenced by the fact that of the 260 joint ventures which were opened between 1995 to 1997 , only two were with Russian money (Batchikov 1997, 2). Furthermore, in December 2000 while in Cuba, Putin stated 'We lost a lot of positions which were a top priority for both countries, and our Russian companies in Cuba have been replaced by Western competitors' (Newman 2000). Both a Russian wish to counter this situation and also that a number of Russian companies that had survived the Russian economic transition were able to invest abroad resulted in Russia being Cuba's largest trading partner in 1996 (Anuario Estadístico de Cuba 2000: VI-5-VI-7; Bain 2008, 64-68). This had not been expected or predicted by experts in the early 1990s. Unforeseen consequences of neoliberal economic thinking in conjunction with the aforementioned Soviet legacy were important for bilateral trade. It was mutually beneficial as Cuba conducted much needed trade with Russian companies also acquiring profits from this trade. 
This remains the case in the second decade of the the twenty-first century despite trade having fallen. In 2012, 341,228,000 pesos worth of trade was conducted (Annuario Estadistico 2013: 8.4-8.6). However, a desire for bilateral trade to increase exists in both countries, demonstrated in February 2013 when Medvedev was in Havana he commented 'Regrettably, trade between Russia and Cuba is not as high as it should be... There are good investment plans, and investment is developing despite its small volume. I am sure it will grow and our cooperation will expand to many new areas' (Medvedev 2013).

In the post 1992 period a number of different forms of asymmetry are evident. Due to the continuing impact of Washington's individual relationships with Moscow and Havana on Russian-Cuban relations distracted asymmetry once again appears important. Moreover, the relationship could also be seen to display normalized asymmetry. This results from the role of the United States in the relationship over a prolonged period of time and that the relationship was both economically and politically beneficial for Moscow and Havana. Additionally, due to its longevity, mature asymmetry was also evident, with the distance between the two countries not impacting negatively on the relationship.As with the 1960 to 1991 period, the distance between Cuba and the United States appeared more important that the distance between Russia and Cuba for much of the post-Cold War era. This is particularly important as it could be thought the magnitude of the relationship and the exposure of Moscow and Havana to one another would disappear as the rivalry of Russian-U.S. relations diminished in comparison to the Cold War era. The magnitude of the relationship waned and the level of exposure receded, but significantly did not disappear. Aspects of asymmetry appeared indifferent to distance. 


\section{Discussion}

As outlined, role asymmetry appears to be evident in the relationship in the 1960 to 1991 era due to Cuba being described as a superclient/surrogate of the Soviet Union with Havana merely acting on Moscow's orders (Erisman 2000, 33-36). However, Womack believes that unlike in feudal times, explicit role asymmetry is not possible in contemporary international relations due to the 'presumption of sovereign equality' (Womack 2006, 243). However, he partly counters this with the idea that semblances of role asymmetry can exist and provides the example of the United States and United Kingdom after the Suez Crisis (Womack 2006, 243).

In the 1960 to 1991 period of the relationship, Moscow's largesse was crucial for Cuba, but the relationship did not display role asymmetry even in the form that Womack has suggested exists between the U.S and United Kingdom. This ignores Castro continually exerting leverage over Moscow, primarily due to the prominence of both nationalism and realist pragmatism within the Cuban ruling elite, with Erisman describing what appeared as counter dependency (Erisman 2000, 43-47). This was important as was Cuba refusing to succumb to the power of the U.S. Simply Cuba had defied the stronger states in both of its asymmetric relationships. Moreover, the type of asymmetry, but particularly role asymmetry, is further questioned by the relative gains vis-a-vis U.S. power that Moscow obtained from its relationship with Cuba. This phenomenon was unaffected by the geographical distance between the two countries and provides a global example of Moscow being unable to impose its authority at will on smaller powers.

As argued, since November 1917 Havana's relationship with Moscow has been part of a triangular formation due to the constant role of the U.S. within it. Cuba has had an asymmetric relationship with both countries with Moscow's relationship with Washington 
also becoming asymmetric in the period since 1992. The result is that the relationship between Moscow and Havana could be described as displaying distracted asymmetry which 'occurs when both sides have to confront more important relationships' (Womack 2006, 243). A robust relationship between Moscow and Havana has been an attempt to counter U.S. hostility towards both countries. The idea of distracted asymmetry is partly questioned by the importance of Marxist-Leninism to the relationship in the 1960 to 1991 period. However, this constant role of the United States, discounting the early to mid-1990s when Moscow pursued a more Western orientated foreign policy, could even suggest that the relationship between Moscow and Havana is one of normalised asymmetry as it has this mutually beneficial effect for both countries. Furthermore, it could be perceived as having been normalised from its start due to the role of the United States.

However, this ignores the political upheaval in both Havana and Moscow, most noticeable in the early 1960s and 1990s, respectively, which makes the relationship being described as normalised throughout its existence impossible due to normalized asymmetry abhorring novelty. Additionally, the relationship was severed in the early 1950s and in the early 1990s little semblance of its previous form continued to function making it far removed from a normalised asymmetric relationship. This also applies to the idea that Russian-Cuban relations could display mature asymmetry, which provides the 'management' of asymmetric relationships (Womack 2006, 247) . Furthermore, this disregards the vastly different ideologies, Marxist-Leninism and neoliberal economics that have impinged on the relationship because it would appear somewhat incongruous if a relationship was classed as normalised over an extended period of time but that this had resulted from such divergently opposing concepts. Moreover, it appears that the geographical proximity of Cuba to the United States has been more significant for both the intensity of the relationship and also the exposure of Russia and Cuba to one another rather than the distance between Moscow and 
Havana. Additionally, a legacy of the exposure of the 1960 to 1991 era has resulted in a degree of exposure continuing to impinge the relationship.

As detailed, sugar has impacted on the relationship in all three eras. Due to its mutually beneficial nature this could also imply that normalized asymmetry is apparent. However, describing the relationship in this manner in the earliest period is impossible as diplomatic relations did not exist when Moscow bought Cuban sugar in the 1950s. Cuban sugar has been important for the Kremlin throughout the three periods examined, but describing the relationship as demonstrating dependent asymmetry is extreme for Moscow. . However, Cuba was economically dependent on the Soviet Union in the 1960 to 1991 period. The relationship between Moscow and Havana displays a number of types of asymmetry, but what is beyond doubt is that it has been important for both countries over a prolonged period of time and has been unaffected by the distance between them.

A study of Moscow's relationship with Cuba since November 1917 posits that aspects of asymmetry are unaffected by distance and that the intensity of an asymmetric relationship is not decided by the geographical proximity of the two countries, but rather by other factors. This includes economic and political aspects, the level of exposure of the two countries to one another and the role of third-party countries. Moreover, the magnitude of the asymmetric relationship is unaffected by the type of asymmetry which exists..

\section{Conclusions}

Relations between Moscow and Havana since November 1917 exhibit a number of the different types of asymmetric power posited by Womack, with it also displaying Womack's idea that a relationship can evolve and move from one type of asymmetry to 
another. Crucially, the distance between the two countries has reduced neither its intensity nor the exposure of Moscow and Havana to one another, Instead it was the geographical proximity of Cuba and the United States, and not the distance between Moscow and Havana that increased both. . Significantly, this existed when Moscow's relationship with Washington was both symmetric and asymmetric. However, it was intensified during the symmetry of the Cold War era.

Furthermore, the relationship between Moscow and Havana suggests that the importance of the relationship is unaffected by the type of governments in power as this has occurred when both were socialist and also when one was capitalist and one was socialist. It could be argued that globalisation has reduced the importance of distance between the two countries in an asymmetric relationship. However, relations between Moscow and Havana may have their own nuances and idiosyncrasies, but over an extended period of time of close to 100 years demonstrate that distance has never been a key factor in reducing the importance and magnitude of an asymmetric relationship with many asymmetric elements being indifferent to distance. The role of third-party countries is important, but the intensity of an asymmetric relationship is not driven by distance, but rather other factors with the exposure that exists between two countries being both paramount, unaffected by, and more significant than distance. In the twenty-first century this is important for understanding the interactions of states of unequal size in international relations.

\section{References}

Adibekov, G.M., Shakhnazarova, E.E., \& Shirinia,K.K., (1997) Organizatsionnaia struktura Kominterna 1919-1943, (Moscow: ROSSPEN).

Anuario Estadístico de Cuba, 1990-2013. http://www.one.cu/ 
Andrew, Christopher \& Mitrokhin, Vasili (2005) The World was Going our Way. The KGB and the Battle for the Third World, ( New York: Basic Books).

Azicri, Max (2000) Cuba Today and Tomorrow. Reinventing Socialism. (Gainesville: University Press of Florida).

'Backing Ukraine's territorial integrity, UN Assembly declares Crimea referendum invalid' (2014) 27 March, http://www.un.org/apps/news/story.asp?NewsID=47443\#.VIHiSHNFAdU Accessed 2 April 2014.

Bai, Yevgeny (1992) 'Toricelli Bill Also Affects Russia. U.S. Toughens Sanctions Against Cuba,' Izvestia, 26 October, 7.

Bain, Mervyn, J,. (2007) Soviet-Cuban Relations 1985 to 1991. Changing Perceptions in Moscow and Havana. (Lanham: Lexington Books).

Bain, Mervyn, J., (2008) Russian-Cuban Relations Since 1992. Continuing Camaraderie in a Post-Soviet World. (Lanham: Lexington Books).

Bain, Mervyn J., (2013) From Lenin to Castro, 1917 to 1959. Early Encounters Between Moscow and Havana, (Lanham; Lexington Books).

Batchikov, S. (1997) 'The Cuba That We are Losing \& Everyone Else is Finding.' Nezavisimaya gazeta, 14 November, 2.

Brenner, Philip (2006) 'Overcoming Asymmetry. Is a Normal U.S.-Cuban Relationship Possible.' in Michael Erisman \& John Kirk (eds) Redefining Cuban Foreign Policy. The Impact of the "Special Period," (Gainesville: University Press of Florida), 281-304.

Carr, Barry (1998) 'From Caribbean backwater to revolutionary opportunity: Cuba's evolving relationship with the Comintern, 1925-34' in Tim Rees and Andrew Thorpe (eds) International Communism and the Communist International 1919-43, (Manchester: Manchester University Press), 234-251.

'Cuba,' (2015) GlobalSecurity.org, http://www.globalsecurity.org/military/world/cuba/intro.htm. Accessed 12 June 2015.

Domínguez, J (1997) 'U.S.-Cuban Relations: From the Cold War to the Colder War' Journal of of Interamerican Studies and World Affairs, Volume 39, No3 (Autumn), 49-75.

Economic Commission for Latin America and the Caribbean (CEPAL), (1990) (Santiago, Chile: United Nations).

Erisman, Michael. (2000) Cuba's Foreign Relations in a Post-Soviet World. (Gainesville: University Press of Florida).

Erisman, Michael (2006) 'Between a Rock and a Hard Place: Survival Strategy in Cuba's New Foreign Policy,' in Michael Erisman \& John Kirk (eds) Redefining Cuban Foreign Policy. The Impact of the 'Special Period,' (Gainesville: University Press of Florida) 1-22. 
Feinsilver, Julie M, (1993) Healing the Masses. Cuban Health Politics at Home and Abroad, (Berkley: University of California Press).

Farber, Samuel (2006) The Origins of the Cuban Revolution. Reconsidered (Chapel Hill: The University of North Carolina Press).

Fursenko, Aleksandr \& Naftali, Timothy (1997) 'One Hell of a Gamble' The Secret History of the Cuban Missile Crisis, (London: John Murray).

Glasov, I., Kara-Murza, G,. and Batchikov, A. (2007) El Libro Blanco. Las reformas neoliberales en Rusia, 1991-2004, (Havana: Editorial de Ciencias Sociales).

Hosking, Geoffrey (1992) A History of the Soviet Union 1917-1991 (London: Fontana Press). Izvestia (1992) 25 November, 5.

Kirk, J.H. (2006) 'Defying the Odds: Five Conclusions about Cuban Foreign Policy,' in Michael Erisman \& John Kirk (eds) Redefining Cuban Foreign Policy. The Impact of the 'Special Period,' (Gainesville: University Press of Florida), 333-344.

Kramer, Andrew (2014) 'Russia Plans to Reopen Post in Cuba for Spying,' New York Times, 16 July, http://www.nytimes.com/2014/07/17/world/americas/russia-to-reopen-spying-postin-cuba.html? Accessed 24 July 2014.

LaFeber, Walter, (1989) The American Age. United States Foreign Policy at Home and Abroad since 1750. (New York: W.W. Norton \& Company).

Larin, E.A. (2007) Politicheskaia istorii Kuba XX Veka. (Moscow: Visshaya shkola).

Lavrentyev, V, (1985) 'USSR-Cuban Brotherhood and Cooperation', (FBIS LD182341 Moscow Domestic Service in Russian 061518 April 1985).

Light, Margot (1996) 'Foreign Policy Thinking' in Alex Pravda, Roy Alison \& Margot Light (eds) Internal Factors in Russian Foreign Policy, (Oxford: Oxford University Press), 33-100.

Letter from Secretariat of the Communist International to PCC, 5 January 1928, Russian State Archive for Social and Political History (RGASPI) RGASPI Folio495, Opus105, No10, $1-7$.

Loss, Jacqueline, (2013) Dreaming in Russian. The Cuban Soviet Imaginary. (Austin: University Press of Texas).

Mamedov, G.E., and Dalmau, A, (2004) Rossiia-Kuba, 1902-2002, dokumenty i materialy, (Moscow, Mezhdunarodnye otnosheniia).

Medvedev, D (2013) Interview with Prensa Latina, Russian Foreign Ministry, 23 February, www.government.ru/docs/22956. Accessed 26 February 2013.

Mesa-Lago, Carmelo (1993) 'The Economic Effects on Cuba of the Downfall of Socialism in the USSR and Eastern Europe,' in Carmelo Mesa-Lago (ed) Cuba After the Cold War. (Pittsburgh: University of Pittsburgh Press) 133-196. 
Mesa-Lago, C. \& Pérez-López, J. (2005) Cuba's Aborted Reform. Socioeconomic Effects, International Comparisons, and Transition Policies, (Gainesville: University Press of Florida).

Morgenthau, Hans (1955) Politics Among Nations. (New York: Knopf).

Pagliery, Felipe (2015), 'Russian senator backs Cuban conditions for relations with U.S.,' progresso weekly, 18 March, http://progresoweekly.us/russian-senator-backs-cubanconditions-for-relations-with-u-s/. Accessed 21 March 2015.

Pérez- López, J. (1997) 'The Cuban Economy in the Age of Hemispheric Integration,' Journal of Interamerican Studies and World Affairs, Vol 39, No 3, 15-22.

Pérez, Louis A, (2003) Cuba and the United States: Ties of Singular Intimacy. (Athens, Ga: University of Georgia Press).

Pravda (1952) 5 April, 3.

Putin, Vladimir, (2014) 'Putin por una Amerika Latina India, sostenible e independiente,' Granma 11 July, 8-9.

Reuters Cuban Correspondent (2000), "Putin to Visit Russia's Former Cold war Ally Cuba" CNN.com 12 December 2000. Accessed 14 April 2005.

Rossiiskaya gazeta (1999) 26 March, 2.

'Russian Military Personnel,' (2015) GlobalSecurity.org, http://www.globalsecurity.org/military/world/russia/personnel.htm. Accessed 12 June 2015.

Schmitt, Michael N (2007) Asymmetrical Warfare and International Humanitarian Law, in W.H.V. Heinegg and V. Epping International Humanitarian Law Facing New Challenges, (Springer: New York), 11-48.

Sevodnya 13 Jan 1995, 3.

Shearman, Peter, (1987) The Soviet Union and Cuba. (London: Routledge \& Kegan Paul).

Shevtsova, Lilia, 2007, Russia Lost in Translation. The Yeltsin and Putin Legacies, (Washington: Carnegie Endowment for Peace).

Shultz, Lars (2011) That Infernal Little Cuban Republic (Chapel Hill: The University of North Carolina Press)

Slobodchikoff, Michael, O., (2014) Building Hegomonic Order Russia's Way. Order, Stability, and Predictability in the Post-Soviet Space, (Lanham: Lexington Books).

Smith, W.S. (1987), The Closest of Enenies. A Personal and Diplomatic Account of U.S.Cuban Relations Since 1957, (New York: W.W. Norton \& Company, New York). 
Sosnovsky, A, (1996) 'On the Benefit of Routine Professionalism' Moskovskiye novosti, No21, 26 May-2 June, 5.

Stern, Ludmila (1999) 'The All-Union Society for Cultural Relations with Foreign Countries and French Intellectuals, 1925-29' Australian Journal of Politics and History, Volume 45, Number 1, 99-109.

Sweig, Julia E., (2002) Inside the Cuban Revolution. Fidel Castro and the Urban Underground, (Harvard University Press, Cambridge, Massachusetts).

Thomas, Hugh (1971) Cuba or the Pursuit of Freedom. (London: Eyre \& Spottiswoode).

Thucydides, (1998) The Peloponnesian War. (Indianapolis: Hackett Pub, Co).

'Transcript of Meeting between US Secretary of state Alexander M.Haig, Jr, and Cuban Vice Premier Carlos Rafael Rodríguez, Mexico City, 23 November 1981' in Cold War International History Project Bulletin, Issues 8-9, 210.

United Nations (1996), 3683ed Meeting of United Nations Security Council, 26July, http://www.undemocracy.com/securitycouncil/meeting_3683, accessed 15 July 2011.

US: Cuban Liberty \& Democratic (Libertad) Act of 1996 (Helms-Burton Act).

Vneshniaia torgovlia SSSR statisticheskii sbornik 1918-1966, (1967) (Moscow:

'Mezdunarodnye otnosheniia,').

White, Stephen, (2004). Russia's New Politics. The Management of a Postcommunist Society, Cambridge: Cambridge University Press).

Womack, Brantly (2003) 'Asymmetry and Systemic Misperception: China, Vietnam and Cambodia during the 1970s' The Journal of Strategic Studies, Vol26, No 2, (June), 92-119.

Womack, Brantly (2006) China and Vietnam: The Politics of Asymmetry, (Cambridge: Cambridge University Press).

Womack, Brantly (2010) China Among Unequals: Asymmetric Foreign Relationships In Asia (Singapore: World Scientific Publishing Company).

Womack, Brantly (2014) 'How Size Matters: The United States, China and Asymmetry' in Quansheng Zhao (ed) Future Trends in East Asian International Relations: Security, Politics, and Economics in the 21 st Century, (New York: Routledge). 